\title{
STUDENTS, PROFESSORS, AND SEXUAL DIVERSITY: ACKNOWLEDGING LGBT+ STUDENTS AND THEIR SCHOOL EXPERIENCE IN UNIVERSITY
}

\author{
Migdelina Andrea Espinoza Romero, José Raúl Rodríguez Jiménez, Daniela Pierson \\ Universidad de Sonora, México
}

\begin{tabular}{l} 
KEYWORDS \\
\hline Higher education, \\
Professors, \\
LGBT+ students, \\
Sexual diversity, \\
Inclusive education
\end{tabular}

\begin{abstract}
This paper aims to explore the interactions between university professors and higher education students who identify as lesbian, gay, bisexual, transsexual, transgender, intersex, queer, and other non-heterosexual identities or orientations (LGBT+). Three theoretical-methodological dimensions are used to explore: a) the academic experiences of LGBT+ university students and the interactions with their university professors; b) the institutional and academic approaches towards sexual diversity in the student population; and c) aspects of their sexual identity. A descriptive case study was designed and the empirical information that supported it came from 31 interviews conducted with LGBT+ university students, enrolled in 11 higher education institutions in Sonora, Mexico.
\end{abstract}

The findings indicate professors abuse their power as teachers: they impose heteronormative interactions in the classroom, discriminating against and acting hostile towards LGBT+ students, negatively affecting them in academic and emotional ways. Only in a few cases, professors displayed inclusive pedagogical practices in front of sexual diversity.

This study shows that being an LGBT+ student negatively affects their learning, because respect for their diversity, a fundamental human right, is compromised by their sexual orientation, resulting in unequal treatment in higher education institutions. Governments and institutions must promote actions for the full integration of these students into academic spaces, where their rights are recognized and respected. In these possible actions, the role of the professor is especially important, because it's a key factor for the successful inclusion of LGBT+ students in higher education institutions. 


\section{Introduction}

$\mathrm{E}$ ven before the COVID-19 pandemic that closed universities, young women students of higher education institutions in Mexico had a prominent place in the national press for their notorious protests denouncing sexual harassment they experienced at their universities. \#MeToo was the hashtag students used in social networks to invite young women around the country to anonymously denounce professors, classmates, and university staff who took part in sexual harassment. The female students in Mexico protested to show discontent with the negative attitudes towards women found in their postsecondary campuses. However, this group of students is not the only one that reports sexual harassment and other forms of aggression, also LGBT+ student community has declared severe discrimination and bullying within the institutions, attitudes that primarily come from their professors and university staff. Thus, universities and other higher education institutions in Mexico are in debt with their main actors: the diverse student community.

Even though there is plenty of specialized literature about the Mexican student population (Guzman, 2011), sexual diversity amongst university students does not seem to be of great interest for national researchers. There is null or limited knowledge of university students identified as lesbian, gay, bisexual, transsexual, transgender, intersex, queer, and other nonheterosexual identities or orientations (LGBT+). Governmental agencies, higher education institutions, and other organizations do not solicit information about this group. There is a systemic avoidance surrounding the gender diversity of the student population.

Therefore, schools and academic places have been identified as unsafe, negative, and hostile for the LGBT+ population due to a lack of policies, practices, and guidelines that promote gender diversity and inclusivity, as well as the creation of safe classrooms and academic environments in support of sexual diversity (Goehring \& Whittington, 2017; Méndez-Tapia, 2017). Likewise, Mexican society shows negative perceptions and attitudes regarding sexual diversity, $60 \%$ of the LGBT+ population declares discrimination, and more than half reports being the target of hostile attitudes, hate, and even physical aggression. During the period 20132018, 473 people were murdered due to their sexual identity or orientation (Letra, 2019). Although the state of Sonora does not have the highest number of discriminatory sexual practices (CONAPRED, 2017), it still maintains a disrespectful culture for sexual diversity (Núñez, 2002; Zatarain, Núñez \& Noriega, 2019).

Despite the fact that students experience homophobia in postsecondary education campuses, there is insufficient information to indicate how they adventure higher education. Dubet (1994) states that students experience higher education from simultaneous processes of socialization and individualization, conceptualized by them as school experience. Thus, the school experience is a reflective process which defines and re-defines the actions of the individuals (Gobato, 2016) and also it varies according to the type of students. Although these authors do not highlight the sexuality of the students as a modifier of the school experience, it may be a component that influences this process.

Under this perspective, self-identified LGBT+ students enrolled in universities in the state of Sonora were invited to participate in this research, an invitation that was accepted by 31 students. The main findings confirm that the sexual orientation of students determines their school experience, an experience marked above all by discrimination and violence. These discriminatory practices are carried out by their own teachers who tend to exercise it and disguise it as a pedagogical resource.

\section{LGBT+ students, in the darkness}

In the last three decades, the Mexican higher education system increased exponentially from 1.1 million in 1990 to 4.9 million in 2020 (SEP, 2020). This increment captivated the attention of educational researchers to start questioning who the higher education students are, their social background, their school practices, and beliefs (Guzmán, 2011). Similarly, some studies have been done to explore students' pathways in higher education, women's involvement in university and academic life as well as maternity 
in female students, and sexual harassment in university classrooms.

According to the literature available, university students in Mexico are evenly divided between female and male sexes; they come from the middle class, although some students belong to vulnerable groups of the population. Postsecondary education students are mainly single and some of the study and work concurrently and most attend public universities. Regardless of this information, sexual diversity hasn't been sufficiently addressed in the Mexican higher education system. There is a deficit in the literature about LGBT+ students, hence the information at hand focuses on describing homophobic academic climates. Even the official information on students in Mexico, both in universities and in government agencies, is reduced to the male/female binary system, so officially sexual diversity is non-existent. Therefore, LGBT+ students remain in the darkness of discriminatory pedagogical practices and hostile classroom environments.

Various reasons may explain the lack of knowledge about LGBT+ university students' experiences. On the one hand, research about sexual diversity is relatively recent in Mexico. It wasn't until the 1990's that the Social Sciences separated from heteronormative reductionist thinking about sexuality and proposed to address it as a complex social construction that involves the subjectivization of the individuals, the social relationships, and the social institutions that are involved (Szasz \& Lemer, 1998). To date, Freud's (1905) psychodynamic and psychosexual development theories stand out as a theoretical reference to interpret the diversity of sexualities. Accordingly, this theoretical field is still in construction and creating a horizon for research inquiry.

On the other hand, social and political movements recognized sexual minorities. The first public LGBT+ demonstrations date back to the late 1970s and were concentrated in Mexico City and Guadalajara (Franco, 2019). Although it is not until the beginning of this century that social movements achieved the recognition of legal rights for LGBT+ people such as marriage between people same-sex couples, adoption for same-sex couples, the creation of laws to stop discrimination, and the acknowledgment of gender identity for transgender and transsexual people over 18 years of age.

In Mexican universities, recent student protests are aimed at respecting the rights of students, especially to stop sexual harassment, even in all public universities in the country there are offices for gender equality and protocols were recently designed to prevent sexual harassment, which is more than reasonable given the levels of violence against women that exist in the country. However, nothing like this exists to protect and promote LGBT+ students' rights and inclusion in the classroom.

Without official data or institutional recognition, without the presence of public organizations to demand respect for their rights, and a recently created field of research that begins the exploration of the wide and complex range of expressions of sexualities, it is understandable that LGBT+ students are not consistently featured on investigative agendas.

Consequently, what happens to LGBT+ students in terms of relationships with teachers and with their classmates as well as their beliefs seem to be non-existent or unimportant. Nonetheless, these students exist and are important since they are part of Mexican higher education.

\section{Higher education and sexual diversity, a possible connection}

Research on LGBT+ students requires the study of two theoretical areas: students and sexualities. Higher education students are often considered as individuals, learning one of the professions offered in school institutions, but they also represent the diversity of social roles. Bourdieu y Passeron (1964) were some of the first authors in comprehending the sociological dimension of the students. In the 60 s, they published -Les heriters y La reproduction- to address this aspect. Schools are institutions that reproduce and legitimize the social differentiation in the student community. Students who come from educated families have more chances to do better in schools due to their cultural and symbolic capital and the development of habitus, understood as a set of principles of perception, appreciation, and 
performance, which allows them to successfully navigate the educational institution.

According to Bourdieu and Passeron (1964), higher education students are predominantly heirs of privileged families, who are economically and culturally favored. The data on French higher education during the '60s supported the previous reasoning since the majority of the students had a privileged social origin.

The massification of higher education in the '70s represented the arrival of students from different social classes, mostly, middle class. Dubet (1994) considers two dimensions to approach the analysis of students such as youth and, what and where they study. For the first dimension, social conditions define different ways of living amongst the youth, for instance, young people from vulnerable families may become part of the workforce while they study at the university, even if they are gifted students. The second dimension involves the institutions and the majors that students choose to study such as hard sciences, social sciences, or arts and humanities.

Dubet (1994) and Dubet and Martucelli (1996) conceptualize this process as a school experience, understood as a process of socialization -institutional and disciplinary- and individualization. Generally speaking, students, while in university, acquire knowledge about the rules and norms of the establishment and also about their professions. The school experience that these authors proposed is constructed by three essential aspects: integration into the school framework, construction of the social utility of their studies -life project-, and vocation as the personal and intellectual interest in their careers (Dubet, 1994).

Although Dubet's (1994) proposal comprehends most of the aspects that students undergo in university, sexual diversity is not recognized as a big modifier of the school experience. In this research, we consider that sexual diversity influences the school experience. For instance, there are sciences or majors with more female enrollment. In the case of social sciences, there are several majors with a female majority while other majors like the exact or hard sciences enroll more men than women (Brunner, 2007).

\section{Sexual diversity and LGBT+ school experience}

School experience may have multiple meanings since experience is a set of subjective aspects, emotional understanding of the reality, and adaptation strategies, all of which forms part of the process of subjectivation but also it is a way to respond to what the society determines. Thus, the experience is framed between individual desires of the subject and the need to respond with expected actions in a given society (Dubet, 1994). In its epistemological definition, the experience is defined as an inner process but also implies a dialogue between the subject and his social interactions, it represents individual historicity originated in specific situations happening in specific institutions and/or establishments (Gobato, 2016).

In order to explore the school experience for LGBT+ students in higher education, a multidisciplinary theoretical framework was developed. Under this guide, it was possible to conceptually connect sexual diversity, university students, and educational establishments.

Sexuality is present in human beings as biological, anatomical, cultural, and social, characterized by different stages of individual development (Papalia, et ál., 2011). Sex and gender play a very important role in understanding sexuality. Sex refers to the anatomical condition of being a man or a woman, while gender is the expression of the masculine and feminine, and is socially constructed. Historically, there have been two aspects to the understanding of the sex-gender relationship. In the first, the traditional logic of human sexuality considers the birth sex as a differentiator of social relations, linking the man with the masculine gender and the woman with the feminine, creating a binary system to identify sexualities, but ignoring that this system generates identities, roles, and practices that are in opposition (West \& Zimmerman, 1987). In the second, gender is conceived as a social construction, a category that allows the organization of human relationships, starting from the differences between masculine and feminine (Scott, 1999). This conception makes visible the dimensions, variations, and 
combinations of the sexualities as illustrated by the interaction between masculine and feminine and the generation of sexualities from this interaction (Van-Anders, 2015). For instance, women can identify themselves with the masculine and men can identify themselves with the feminine.

The acronym LGBT+ has become an internationally recognized term that represents the population who identifies with sexuality that goes beyond traditional logic and is made up of the initial letters for: lesbian, gay, bisexual, transsexual, transgender, intersex, and queer, but it is not limited to these orientations, since with the + symbol, it expresses the inclusion of other non-heterosexual orientations.

Sexual diversity may represent a challenge for heteronormative societal or institutional frameworks since it questions and disobeys the social guidelines marked by traditional sexual logic (Foucault, 1977; Vince, 1991). In some societies, the LGBT+ population receives disapproval, intolerance, prejudice, and these people's lives are even threatened. In 2015, Mexico ranked second in the world for homophobic crime and, unfortunately, these events occur more frequently in schools $(\mathrm{ICOH}$, 2015; Méndez-Tapia, 2017).

The population considered in this study expressed that school environments and school experience stimulated their discovery as LGBT+ subjects. In the LGBT+ school experience, the social and the personal are interwoven, on the one hand, the academic project of the students, the vocation by a career, the sense of belonging to the university, and on the other hand, what the institution expects of them, this is, the adjustment to their regulatory frameworks, their organization, and their own culture. LGBT+ students give meaning to their practices by following the rules, formal and informal, of the establishment and their field of study, which allow or restrict certain behaviors.

As mentioned before, Dubet and the rest of the experts, in analyzing the school experience and students in higher education, have not completed the general portrayal of university students as sexual diversity hasn't been approached under their theoretical lenses. Nonetheless, for this research, Dubet's (1994) theoretical approach in combination with the theoretical framework for sexual diversity is considered. The school experience for LGBT+ students is then understood as a process of subjectivation that occurs within academic environments and in constant adjustment due to social and interpersonal interactions with other members of the university community, especially, those interactions that take place within the classroom.

\section{Methodology: firsts approaches}

This article shows a close up of the LGBT+ students and their school experience in higher education institutions. This analysis presented several methodological challenges. As previously stated, the topic of LGBT+ is controversial in Mexico; those who identify themselves with diverse sexuality remain hidden with their nonheterosexual orientation to avoid being a victim of homophobic acts and bullying, which could have resulted in low student participation in this research. The strongest limitation was the lack of official information, so various methodological strategies were reviewed to meet the objective of this research.

There were two criteria to participate in this study: self-identification as LGBT+ or nonheterosexual and being enrolled in a public or private university in Mexico, preferably at the undergraduate level. This descriptive case study gathers information from the participants through interviews. A digital invitation to participate in this study was published on social networks like Facebook, Twitter, and WhatsApp; it was also sent by email to members of civil associations focused on sexual diversity issues, faculty and peers from various public and private universities, and activist leaders belonging to LGBT + communities in the state of Sonora, Mexico. The solicitation was broadcast virtually for six months; 27 requests for information were received through email and five through WhatsApp; it was shared 49 times on Twitter, while the publication on Facebook had a reach of 4,684 people, 231 interacted with the call, 55 people clicked on the Like button; it was also shared 54 times and had 23 conversations, which indicates that the topic generates great attention among students and other social sectors. However, the number of university students with 
whom the interview was carried out involved 31 participants.

The interviews were audio-recorded and transcribed, to later be processed and analyzed in the ATLAS.ti 8.4 programs. Three initial theoretical-methodological dimensions allowed us to explore: a) the school experiences of LGBT+ university students, considering the relationship between them and their teachers; b) their opinion about the academic establishment, especially about its approach towards sexual diversity; and c) aspects of their sexual identity. By analyzing the information provided by the respondents, new categories of study emerged, the perceptions of the LGBT+ students about how faculty face and respond to sexual diversity in the classroom. As part of the study, a fictitious name was assigned to each of the participants and identification labels were created containing information on their sexual orientation and institutional affiliation as students.

The participants were enrolled in 11 universities, three public and eight private. The most frequent sexual orientation among them was gay, although bisexuals, lesbians, queers, transgender, and transsexual people also appeared (Table 1).

Table 1. General information of the participants

\begin{tabular}{lcccccc}
\hline Sexual orientation & \multicolumn{2}{c}{ Visibility } & \multicolumn{2}{c}{ HIED Institution } & Average age \\
& Cases & Open & Discrete & Public & Private & \\
\hline $\begin{array}{l}\text { Transgender and } \\
\text { transsexual }\end{array}$ & 2 & 1 & 1 & 1 & 1 & 29 (SD 6) \\
\hline Queer & 2 & 0 & 2 & 2 & 0 & 23 (SD 0) \\
\hline Lesbian & 6 & 2 & 4 & 4 & 2 & $23.83(6.55)$ \\
\hline Bisexual & 8 & 4 & 4 & 6 & 2 & 23 (SD 3.02) \\
\hline Gay & 13 & 7 & 6 & 8 & 5 & 22.92 (SD 3.86) \\
\hline Total & 31 & 14 & 17 & $21^{*}$ & $10^{*}$ & 23.5 (SD 4.3)
\end{tabular}

Note: *The figures correspond to the institutional location of the interviewees, but not to the total number of establishments.

Source: own elaboration with the information provided by the participants of this research.

The interviewees are young students, with an average age of 23.5 years (SD 4.3), the majority of them are from the state of Sonora and have a grade point average of 87.90 (SD 7.70) -scale 0 to $100-$, so they have an acceptable academic performance. Most of them are single and some are living as common-law partners. Only some of them combine their post-secondary education with a job, so they are full-time students and receive financial support from their parents or partner. Regarding science fields (see Table 2), the majority of the students are enrolled in Social sciences and Law, followed by those enrolled in Engineering, Manufacturing, and Construction followed by those who study Education, Administration, and Business while the rest are found in Health Sciences, Arts and Humanities and Services (Mexican classification of fields of study of INEGI, 2016).

Table 2. Fields of study of the interviewees

\begin{tabular}{lc}
\hline \multicolumn{1}{c}{ Field of study } & Cases \\
\hline Social sciences and Law & 11 \\
\hline Engineering, Manufacturing, and Construction & 7 \\
\hline Education & 5 \\
\hline Administration and Business & 4 \\
\hline Health Sciences & 2 \\
\hline Arts and Humanities & 1 \\
\hline Services & 31 \\
\hline Total & 1 \\
\hline $\begin{array}{l}\text { Source: own elaboration with the information provided } \\
\text { by the participants of this research using the Mexican } \\
\text { classification of fields of study of the INEGI, 2016. }\end{array}$ &
\end{tabular}


Most of the interviewees are enrolled in the oldest and most populous public university in the state and are taking fifth-semester courses of nine- of their respective bachelor's degrees, so they have already gone through the adaptation stage and it can be said that they fully know the operation of the establishments in which they are enrolled. Three interviewees changed majors during their academic careers. The change of career is associated with issues about their sexual identity in which their teachers or other students treated them negatively, and also because they went through an emotional crisis that forced them to abandon their first or second major. For 17 of the 31 interviewees, their sexual identity is a particular issue, since their visibility is discreet; while the rest of the students have managed to express open and public visibility. Most visibly recognized LGBT+ students belong to public universities, while those who belong to private universities are discreet in their preferences.

In Mexico, higher education institutions present notoriously characteristics depending on the source of funding. Thus, institutions receiving financial support and funding from public resources tend to be tolerant of the political and cultural orientation of their students, including the defense of women's rights, while universities belonging to the private sector, which is the most numerous in the country, tend to be more traditional with respect to their students and their thoughts, attitudes, and expressions, so they are often less tolerant and inclusive.

\section{Findings: looking at university professors through LGBT+ students' lenses}

The information obtained with this study confirms that the university professor is a key actor in school life. Teachers are essential in the transmission of knowledge and, of course, in the evaluation of learning, but the case of the participants of this research, meaning students with diverse sexual orientations, the role of the teacher involves other responsibilities, as he or she plays a key role in who may facilitate or obstruct the experience and success of LGBT+ students in higher education.

The literature indicates two types of leadership in university professors: the positive and the negative model (Hill, 2013; Evans, 2015). The first model refers to professors who serve and benefit students with their support, it also includes those who voluntarily adopt the role of mentors or tutors for students who are just starting their majors, and also those students who are part of the university workforce, but who are younger than the leader. On the contrary, the negative leadership model refers to those teachers who serve as an example of what should not be done, in most cases, their negative leadership is not something planned.

Hence, teachers have a fundamental role with regard to inclusive classrooms, since they can promote equity and equal opportunities for all students, however, they can also serve as obstacles for the full development of their students (Hargreaves \& Fink, 2006). During their school experience in university, the interviewees have encountered two types of teachers; on the one hand, teachers respectful of sexual diversity; on the other hand, teachers who are intolerant and bullying with any person that does not identify with the heteronormative model.

Professors who are tolerant and respectful of diversity are limited, and fortunately, they have had a notorious and critical role in the school experience of the interviewees. These professors have carried out actions to advocate LGBT+ students' rights, demanding and enforcing inclusion and respect in their classroom and on the university campus.

At the beginning of each semester, I write an email to each of my professors to inform them that I am going through a sex reassignment process, and that the name that appears on the attendance list is no longer mine, because now my name is different. I ask that they please call me with my man's name, not with the woman's, or preferably by my last name. Few teachers respond positively to my request and those who do are also excellent teachers at an academic level. (Ulises, TsPrS09-03)

Those few teachers are usually mature, around 60 or 70 years old, who prepare each of their classes and who can be trusted to consult 
regarding school problems, but also discuss questions about sexual diversity.

One of my sociology teachers is about 60 years old and always supports students who belong to the LGBT+ community. She keeps us informed through media when conferences on this matter are scheduled and also advises us in the event of being victims of homophobic acts. She is an advocate of women's rights and sexual diversity. (Hércules, GPuCSD05-09)

This group of professors are predominantly female and are affiliated with 6 of the 11 universities that took part in this study. They fill institutional gaps in attention to issues that involve the diverse student population. They are knowledgeable about their university policies, rules, and norms and aware of the subtle, implicit, and sometimes silent exclusion practices performed against sexually diverse students; they have gathered enough experience to lead school groups in defense of students' rights; they are experts in social sciencessociology or psychology, and are sensitive to problems and situations that LGBT+ students may face, they perform as tutors, and even as advocates for LGBT+ students. For the interviewees, these teachers are ideal and influenced their school experience in a really positive way since they were irreplaceable support.

Besides studying psychology, I am also an athlete. One day, I was at volleyball practice on the university courts. A group of students men- from another undergraduate degree sat down to observe me and began shouting: "Butch! You win because you play against women! Better play against men! " One of my professors -of psychology- when she realized what was happening, approached them, confronted them and accompanied me to report them with the corresponding authority. (Penélope, LPrCSD09-12)

Unfortunately for the interviewees, these teachers are exceptions, so most of the interviewees are unaware of their existence. Instead, they frequently encounter teachers mostly male - who abuse their power, insult, despise, and stigmatize sexual diversity and those whose identity is outside of heteronormativity. The degree of discrimination perceived usually implies some degree of aggression or violence. According to the interviewees, these teachers are known among students for carrying out discriminatory actions, especially verbal, offending women and people with different sexual orientations. Due to the knowledge of these academics among the students, some interviewees decided not to take courses with them, even if this represented a delay in their graduation.

The professor of the computer science class insults everybody; he makes jokes about women and expresses a negative perception about gays, lesbians and bisexuals. Once, I witnessed how he verbally attacked one of my classmates who was pregnant. The teacher told her that she better go home to take care of her future baby, because college was no longer for her. I would never enroll in his class, even if it takes longer to finish my studies. (Bastian, GPuAH05-15)

The interviewees point out that these teachers attack LGBT+ students on a daily basis and take advantage of any occasion to ridicule them. Furthermore, discrimination was covered as a pedagogical resource to reduce stress, encourage fun for the students, or break the monotony during classes. It is not possible to know if these resources achieved any pedagogical task, but these actions demonstrate no appreciation and courtesy towards students' sexual orientations and their rights whatsoever; in fact, these hostile situations could be considered as factors for the interruption or abandonment of studies.

During my first term in college, the professor for the 7 am class started his class with a joke about gays or lesbians. I never said anything, nor did I express my annoyance to anyone because I didn't want anyone to find out that I am a lesbian. I used to feel bad all day, because I was left with all the repressed sadness. Because of teachers like this and other problems associated with my sexual identity, I stopped studying for a year. I needed to find myself, to know who I was. (Aurora, QPuIMC05-05) 
Stereotypes, prejudices, and preconceptions exist without rational or logical support associated with all genders, the LGBT+ community is not exempt. This collection of ideas is better known as stigma and it consists of erroneous beliefs that damage the image of sexually diverse people (Salter \& Liberman, 2016). Among the stigmas that have historically been associated with the LGBT+ population, there are misconceptions about sexual practices considered as promiscuity, being carriers of all kinds of sexually transmitted diseases, and having inferior intellectual abilities compared to those who are predominantly heterosexual. Furthermore, sexually diverse people have been wrongly labeled as deviant, and have been persecuted for challenging and transgressing the dominant structures of the heteronormative system (Foucault, 1977).

In our study, the stigmas were expressed through mockery, jokes, insults and disrespectful expressions that teachers used as a supposed resource to improve teaching, break the ice and start the class, reduce stress, or simply as collective fun, assuming that among the students there were no an LGBT+ student as they did not have the "appearance" of being such.

My appearance has never been flashy. Now that I am a man, I try to make my physical image completely manly. There are always people who joke about the LGBT+ community. I consider it normal to a certain extent, sexuality is part of life and there is always a joke about anything in life. They do not know that I am transsexual, they do not know who I really am, they assume that I have always been a man and they joke in my presence. But when jokes come from professors, from university professors, then it hurts, it is not acceptable, it is not ethical, it is not a professional attitude. (Ulises, TsPrS09-03)

According to the interviewees, when the teachers specifically speak about sexually diverse students, the tone of discrimination was notably higher. They used adjectives with a strong content of symbolic violence, even though they could be perceived as colloquial terms, these adjectives show an offensive speech against sexually diverse people. The teachers of the interviewees' stories referred to LGBT+ female students as tortilleras, lenchas, machorras, or marimachas ${ }^{1}$, and to refer to men they used adjectives such as "jotos, maricas or putos 2 ".

The highly sexist language promotes erroneous ideas of sexual diversity. The impact is even greater when it comes from a university professor, therefore, LGBT+ students are attacked by stigmas that lack a logical conceptualization and negatively permeate the academic environment (Tusón, 2016).

This explicit and also symbolic aggression and violence against LGBT+ students in university campuses, not only damages their school experience but also affects and contradicts institutional programs addressing issues of sexual diversity on campus. It creates a "normal" and "natural" way to treat sexual diversity and the LGBT+ community. It makes harsh and abusive pedagogical practices a "normal" way to interact with students of any gender.

One day in the Ethics and Professional Development class, we were reviewing the topic of discrimination and the teacher asked about the types of discrimination we knew of. Another student raised her hand and said: "discrimination based on sexual orientation." The teacher laughed out loud and then asked: "Is anyone here joto?" I raised my hand to tell him that that word was not appropriate and to ask him to please not express himself like that, but he did not let me speak and immediately shouted: "see, he is not ashamed of being a joto, this type of discrimination already do not longer exist, these issues are normal." I kept quiet and did not participate in the class anymore. (Orfeo, GPuE01-06)

Besides engaging in discriminatory practices, some teachers engage in sexual harassment. Bullying in higher education has distinctive characteristics, different from bullying at lower educational levels but similar to workplace bullying. In higher education, the victims of bullying are generally the students, while the

\footnotetext{
1 Tortillera, lencha, machorra, marimacha: the words can be used as synonyms. In Mexican colloquial language, they are derogatory terms to refer to a lesbian or a masculine woman.

2 Joto, marica, puto: the words can be used as a synonym. In Mexico, the terms refer to gays or feminine men, denoting a great content of disdain.
} 
bullies can be their peers, and also their teachers. When it is the teacher who sexually harasses his or her students, the damage towards the victims is even greater, since the students tend to give in, maintain and hide the situation out of fear, they suffer deep psychological damage (Romero \& Plata, 2015). However, sexual harassment of sexually diverse students is almost unknown. One of the interviewees recalled that, when she had not yet defined her sexual orientation and had strong doubts about her socio-affective interests, one of her teachers, who was also her academic tutor, found out about her dilemma and started persistent and prolonged harassment with sexual overtones, which led this student to temporarily drop out of university studies.

I was always a good student, I was on the honor roll several times, but I missed a year in college. A journalism teacher suggested that I have sex with her. She threatened to fail me if I did not accept. I rejected her, she carried out her threat and she failed me. I reported her to the Office of Student University Rights. The lawsuit did not proceed because she is married - to a man and, therefore, it was impossible for her to be a lesbian. That teacher also has influence in the college union. They asked me for a lot of evidence, audio and video recordings that provided evidence against the teacher, but obviously I didn't have any. The university did nothing about the teacher, everything remained the same. Nobody believed me for being just a student, and besides being a lesbian, a liar. (Helena, LPuCSD09-02)

Moreover, the stories of our respondents revealed that some teachers directly discriminated and showed hateful attitudes towards specific students in their classrooms by calling them by their full names, also they used these attitudes in order to change LGBT+ students' behaviors. as if they were wrong or inappropriate. These teachers intended to raise a public claim against sexual diversity and demanded students to either change or keep their sexual orientation hidden as this supposedly would benefit students in their professions. Even professors with prestige in their field of work have shown discriminatory and hostile practices, their prizes and public recognition do not motivate them to develop an open-minded attitude free of prejudice.

In law school there are a couple of professors who are recognized for being prestigious lawyers, but also for being misogynistic, racist and elitist. One day during one of the classes, one of these teachers called out my name and asked me: "Do you want to be a lawyer with that hair and with those clothes? The way you look, nobody will give you a job, they won't even distinguish if you are a woman or a man. Nobody is going to hire you; I wouldn't hire you in my law firm. Better, make up your mind and even if you don't like it, act like you're a man. If you don't, you're going to starve. (Theo, QPuCSD08-13)

In education, the classroom is a valuable place where a large part of learning takes place, but also where cohorts of diverse social actors meet. On the one hand, the students who attend college in order to acquire knowledge in their fields of study will need to demonstrate a certain degree of expertise in their professions once they graduate. On the other hand, the professors who teach are leaders in their field of knowledge. It is an unequal relationship based on power, between some who do not yet know and others who dominate knowledge (Stubbs \& Delamont, 1978). The interviewees confirm the importance of the classroom as a space for teaching and learning, but their school experience demonstrates a reality characterized by abuse, discrimination, and hostility notably from faculty. The majority of professors who displayed negative attitudes and bullying were male. They used their power and privileged position to discriminate against those who did not adhere to heteronormative dispositions.

It is important to highlight that these are prestigious professors due to their mastery and professional success in their discipline of study; they could even be considered good teachers if they are evaluated based on the criteria outlined by government programs for the professionalization of academics (Gobierno de la República, 2013). Nonetheless, after analyzing their interactions with LGBT+ students, it is disheartening to find that most of them used a negative academic leadership model. It is possible to consider their practices as 
homophobic, since through the use of stigma, sexism, and pejorative language, they dictate and promote a climate of inequality within the classroom, damaging and leaving those who are sexually diverse at a disadvantage.

\section{Conclusion}

As stated before, the school experience is the process of socialization and subjectivation which students go through during university studies. Having said this, school experience corresponds to three categories: institutional integration, the school project, and the desire to study. In this journey, students establish relationships with key actors. One of them is the teacher. This key actor is committed to teach and provides access to specific knowledge of the field of study as well as evaluate learning. This position grants power, it is legitimized by the educational institution and is valuable and appreciated for students who want to acquire knowledge. Thus, the teacher demands from his or her student's certain activities -homework, exams, essays, to name a few- and behaviors -course attendance, silence in-class sessions-.

Since the last century, students have noticed excesses in the figure of the teacher, the student protests of the 1960s or the current movement of students to stop sexual harassment are good examples of this, so the universities proceeded to establish regulations of ethical behavior for teachers. In Mexico, these regulations exist and have limited certain excesses of teachers, but on issues of diverse sexualities, the actions of teachers do not show respect. According to our interviewees, most of their teachers stand out for their intolerance, disdain, and violence towards sexual diversity.

During the '60s, students noticed how professors were abusing their power. Since then, student protests have addressed sexual harassment coming from teachers, so universities have created regulations in order to encourage ethical behaviors in classrooms and campuses. In Mexico, this set of regulations, norms, and rules are part of universities' normative, and it has set up some limitations to a certain extent. However, sexual diversity still challenges traditional and conservative ways of thinking and heteronormative behaviors.
According to our participants, most of the professors stand out for their intolerance, disrespect, and hostility towards sexual diversity.

Despite the fact that LGBT+ students recognize that the actions of these teachers violate their rights, they do not protest, nor do they report. What is the reason for this attitude? There are several elements that intervene. On the one hand, the interviewees know or intuit that their protests will have no effect whatsoever. Furthermore, students who went to the university authorities to point out the behaviors of their teachers, faced institutional disdain, one of them even had to abandon his studies. Along with institutional disinterest in these issues, LGBT+ students have not developed organizations for the recognition and defense of their rights at universities, so the aggression and hostility may be experienced alone. Under these conditions, some interviewees decide to endure the abuse and violence of their teachers; while some LGBT+ students decide to remain anonymous or hidden -they call it the discretion of their sexual preferences- so they are not identified as sexually diverse. In both cases, they display strategies to navigate the university and get along with their peers. All of this is part of their school experience.

The integration of the rules and regulations that exist in universities involves the understanding of what is allowed and what is prohibited within the school. It also includes the recognition of those areas that are not institutionally regulated and are arbitrarily ordered by certain actors. For instance, the role of the teacher in the classroom and the enforcement of an order that does not tolerate sexual diversity.

The school project of these students is also conditioned by their sexual diversity. All our participants have a professional project that guides their university studies; they are convinced that their studies will be useful in the job market, so they are determined to graduate. They have professional expectations: it would mean a professional accomplishment and it would give them some kind of recognition beyond their sexual orientation: When I realized that I was accepted to become an English 
teacher, I said to myself, "You're doing well, you no longer have to open your aesthetics or beauty studio!" I have never had those interests, I am very masculine, but it took a great weight off my shoulders knowing that I would become a teacher and that I would not be just another gay with little skirts and false eyelashes [laughs] (Tristán, GPuE05-08).

The participants of this study express a vocational attitude towards their majors. Dubet (1994) understands vocation as the interest and identity of the field of study. Students are fully convinced of their vocation for their careers and their familiarization with their universities; however, achieving their professional dreams, they must endure discrimination and violence due to their sexual orientation or decide to hide it.

Despite the fact that the mission and vision of the universities in Mexico should be oriented towards diversity and educational inclusion (ANUIES, 2019), based on what was said by the interviewees, it is possible to point out that the homophobia manifested by society in Mexico also lives in higher education establishments.

From the interviewees' stories, it is possible to discern that the majority of the members of the university community, especially the professors, guide their behavior based on negative beliefs about those who are LGBT+. Is it possible to alter the state of affairs in the universities understudy to accommodate relationships of equality and tolerance? The question goes beyond the purposes of this research, however, institutionalizing inclusion and programs for sexual diversity in universities through the generation of rules, and promoting a culture of respect towards the LGBT+ community, can result in a scenario that takes into account the sexual differences of its members for their academic and social integration.

Dissolving the discrimination against sexually diverse students also includes learning about the complex university life of LGBT+ students. Being a student with a different sexual orientation has a high cost, not only for the learning process of these students but for their diversity or differentiation, a fundamental human right, is compromised by their sexual orientation, resulting in unsafe and unequal treatment on campuses. Although the predominance of the heteronormative system is not an official rule in universities, there are also no regulations that protect LGBT+ students.

From selecting the major or field of study, the academic project of some is aligned with the hetero-norm and not with their genuine vocational interests, due to the fear of showing their sexual diversity:

My first career was Civil Engineering. I always wanted to study Nursing, but nurses are women and I am a man, so it was my obligation to study something for men, such as engineering. The first semester was very difficult, not because of the courses, but because I didn't like what I was studying. I wanted to be a nurse, that was my true calling. At that time, I still did not accept that I was gay and limited myself to doing many things for fear that people would question my sexuality. (Hipólito, GPuCS03-10)

A strong institutional integration is related to dominance, appropriation, and acceptance of the formal and informal rules of the establishment (Dubet, 1994). Thus, LGBT+ students are integrated into the university, they fit into an institution where most of its members legitimize heterosexuality. Their integration has not been easy and they have developed resilience. Despite the homophobic climates they face on a daily basis in their classrooms and in other university spaces, they maintain a positive attitude, forming networks with others who are sexually diverse and with allies. They rely on their studies for future job stability.

The findings show that the role of the professor is key for the full inclusion of LGBT+ students in classrooms and other university spaces. The professor is the one who issues grades and grants approval, but at the same time is a source of professional inspiration for many students, hence it is of utmost importance in relation to the inclusion of sexual diversity in universities.

It is important to recognize that the academic performance and trajectory of the students is not only the responsibility of the teachers but of the universities, so programs for the comprehensive care of LGBT+ students should be promoted, 
focusing on their academic needs and other associated factors, such as timely psychological care and fostering a culture of respect for sexual diversity in universities. Recognizing that the correction of poor teaching practices in the face of sexual diversity will result in more equitable environments.

Governments and other social institutions and civil organizations must promote actions for the full integration of these students into schools, so their rights are recognized and respected. With these possible actions, the role of the university professor should be especially important, since his/her position places him/her in a powerful place to promote practices of inclusion and equality.

Education is a means by which human relations can be transformed, therefore, it is through education that it is possible to generate changes towards equality in a diverse society (OEI, 2018). Promoting and ensuring inclusion for people with different sexual orientations, higher education will expand its teaching functions, not only in the fields of knowledge but also contributing to a truly equitable education that promotes learning opportunities for all people.

\section{Limitations}

Integration strategies displayed in this research are shared with the interviewees; however, as a descriptive case study, it is not possible to state that the experiences described in this study occur to the totality of the diverse student population enrolled in higher education institutions.

Despite caring about the methodological design in order to protect the sexually diverse community, it is to be assumed that certain LGBT+ students discreet in their preferences avoided participating in this research. That is why there is a need for methodological designs that can protect the target population.

\section{Pending agenda}

As a first approach for future studies of LGBT+ university students, the findings of this study should be expanded, confirmed, or corrected by new research. The descriptive scope of the research generated information that opened new questions about the LGBT+ school experience. It is proposed to carry out comparative studies that allow looking deeply into the university school experience of those who are sexually diverse.

The methodological research design only considered enrolled students, but some testimonies indicate that the LGBT+ population has a higher probability of school dropout due to violence and homophobic discrimination. Future research could be directed to find these students and explore how their experience at the university was. 


\section{References}

Asociación Nacional de Universidades e Instituciones de Educación Superior (2014). Género y educación superior, http://www.anuies.mx/noticias/index.php?pag=29

Bourdieu, P. \& Passeron, J. (1964). Los herederos. Los estudiantes y la cultura. México: Siglo Veintiuno, https://socioeducacion.files.wordpress.com/2011/05/bourdieu-pierr-los-herederos.pdf

Brunner, J. (2007). Universidad y sociedad en América Latina. México: Universidad Veracruzana. ISBN 978-968-834-855-0.

Consejo Nacional Para Prevenir la Discriminación (2017). Encuesta Nacional sobre discriminación 2017. Principales resultados. México: CONAPRED, http://www.conapred.org.mx/userfiles/files/PtcionENADIS2017_08.pdf

Dubet, F. (1994). Dimensions et figures de l'expérience étudiante dans l'université de masse. Revue française de sociologie. Monde étudiant et monde scolaire 35(4): 511-532, https://www.persee.fr/doc/rfsoc_0035-2969_1994_num_35_4_4353

Dubet, F. \& Martuccelli, D. (1996). La escuela. Sociología de la experiencia escolar. España: Losada.

Evans, L. (2015). What academics want from their professors: findings from a study of professorial academic leadership in the UK. Cummings, Forming, recruiting and managing the academic profession compilado por Ulrich Teichler y William Cummings: 51-78. Suiza: Springer, https://doi.org/10.1007/978-3-319-16080-1

Foucault, M. (1977). Historia de la sexualidad 1: la voluntad de saber. México: Siglo XXI editores. ISBN 968-23-0118-1, http://www.uruguaypiensa.org.uy/imgnoticias/681.pdf

Franco, C. (2019). El movimiento LGBT en México. Direitos Culturais, https://doi.org/14.275.10.20912/rdc.v14i34.3218.

Freud, S. (1905) Tres ensayos de teoría sexual. Argentina: Amorrortu editores. ISBN 978-950-518-583-2

Gobato, F. (2016). La obsesión participante. Ensayo sobre el método. La experiencia como hecho social. Ensayos de sociología cultural, 29-44. México: FLACSO.

Gobierno de la república (2013). Plan de Desarrollo Nacional de México 2013-2018, http://pnd.gob.mx/

Goehring, C. \& Whittington, H. (2017). Gender diversity and inclusivity in the classroom. Montessori Life 2: 50-53, content/uploads/2017/08/GoehringWhittingtonGenderDiversityMontessoriLife.pdf

Guzmán, C. (2011). Avances y retos en el conocimiento sobre los estudiantes mexicanos de educación superior en la primera década del siglo XX. Perfiles Educativos 23 (1). México: IISUE-UNAM.

Hargreaves, A. \& Fink, D. (2006). Estrategias de cambio y mejora en educación caracterizadas por su relevancia, difusión y continuidad en el tiempo. Revista de Educación, 339, 43-58, https://www.researchgate.net/publication/39218734_Estrategias_de_cambio_y_mejora_en_educa cion_caracterizadas_por_su_relevancia_difusion_y_continuidad_en_el_tiempo

Hill, L. (2013). Lasting female educational leadership. Leadership legacies of women leaders. USA: Springer, https://doi.org/10.1007/978-94-007-5019-7

Hodgson, G. (2011). What are institutions? Ciencias sociales 8(17): 21-53. Colombia: CN. ISSN 2011-0334, http://www.scielo.org.co/pdf/recs/n8/n8a02.pdf

Informe de Crímenes de Odio por Homofobia (2015). Seguimiento hemerográfico de notas informativas sobre este tipo de homicidios de $1995 \mathrm{al} 2015$, http://www.letraese.org.mx/proyectos/proyecto-1-2/

Instituto Nacional de Estadística y Geografía (2016). Clasificación mexicana de planes de estudio por campos de formación académica 2016. Educación superior y media superior. México: INEGI.

Letra (2019). Violencia extrema. Los asesinatos de personas LGBTTT en México: los saldos del sexenio (2013-2018). http://www.letraese.org.mx/wp-content/uploads/2019/05/Informecr\%C3\%ADmenes-2018-v2.pdf

Méndez-Tapia, M. (2017). Reflexiones críticas sobre homofobia, educación y diversidad sexual en Educação \& Realidade, 42 (2): 673-686, http://dx.doi.org/10.1590/2175-623656193 
Núñez, G. (2002). Identidad regional: del discurso del poder al discurso democrático de la diversidad in Sonora frente al siglo XXI. México: El Colegio de Sonora.

Organización de Estados Iberoamericanos (2018). Educación incluyente, gran reto a nivel nacional. Conferencia de apertura del Encuentro de experiencias de educación incluyente: hacia una educación antidiscriminatoria, convocado por CONAPRED, CREFAL, OEI-México y COEPREDV. México: Organización de Iberoamericanos, http://www.oei.org.mx/Oei/Noticia/educacion-incluyente-gran-reto-a-nivel-nacional-alexandra

Papalia, D., Olds, S. \& Fieldman, R. (2011). Desarrollo Humano. México: Editorial McGraw-Hill.

Romero, A. \& Plata, J. (2015). Acoso escolar en universidades en Enseñanza e Investigación en Psicología 20 (3): 266-274, México: Consejo Nacional para la Enseñanza en Investigación en Psicología A.C.

Salter, N. \& Liberman, B. (2016). The influence of sexual orientation and gender on perceptions of successful leadership characteristics. Sexual orientation and transgender issues in organizations. Global perspectives on LGBT workforce diversity: 429-450. Suiza: Springer, https://doi.org/10.1007/978-3-319-29623-4

Scott, J. (1999). El género: una categoría útil para el análisis histórico. Sexualidad, género y roles sexuales. Argentina: Fondo de Cultura Económica. ISBN 950-557-339-1.

Secretaría de Educación Pública (2020). Serie histórica. México: SEP. https://www.planeacion.sep.gob.mx/estadisticaeducativas.aspx

Stubbs, M. \& Delamont, S. (1978). Las relaciones profesor alumno. Barcelona: Oikos-Tau.

Szasz, I. \& Lemer, S. (1998). Sexualidades en México: algunas aproximaciones desde la perspectiva de las ciencias sociales. México: El Colegio de México.

Tusón, A. (2016). Lenguaje, interacción y diferencia sexual. Enunciación 21 (1), 138-151.

Van-Anders, S. (2015). Beyond Sexual Orientation: Integrating Gender/Sex and Diverse Sexualities via Sexual Configurations Theory. Archives of Sexual Behavior 44: 1177-1213, https://doi.org/10.1007//s10508-015-0490-8

Vince, C. (1991). Anthropology rediscovers sexuality: a theoretical comment. Social science \& medicine 33(8): 875-884, https://doi.org/10.1016/0277-9536(91)90259-F.

West, C. \& Zimmerman, D. (1987). Doing gender. Gender and society 1(2): 125-151, https://www.gla.ac.uk/0t4/crcees/files/summerschool/readings/WestZimmerman_1987_DoingG ender.pdf

Zatarain, A., Núñez, G. \& Noriega, N. (2019). "Tortilleras, tamaleras, chanclas y lenchas": representaciones dominantes de las relaciones erótico-afectivas entre mujeres en el norte de México. Revista de Estudios de Antropología Sexual 1(10): 27-45. México: CIAD. 
EDU Review, 8(4), 2020, pp. 207-222

Annex. Interviewees identification data

\begin{tabular}{|c|c|c|c|c|c|c|}
\hline $\begin{array}{l}\text { Interview } \\
\text { number }\end{array}$ & Name* & $\begin{array}{c}\text { Sexual } \\
\text { orientation }\end{array}$ & University & Field of study & Semester & ID tag** \\
\hline 1 & Zeus & Gay & Private 1 & $\begin{array}{l}\text { Engineering, Manufacturing and } \\
\text { Construction }\end{array}$ & 9 & GPrIMC09-01 \\
\hline 2 & Helena & Lesbian & Public 1 & Social sciences and Law & 9 & LPuCSD09-02 \\
\hline 3 & Ulises & Transsexual & Private 2 & Services & 9 & TsPrS09-03 \\
\hline 4 & Aquiles & Gay & Public 1 & Education & 5 & GPuE05-04 \\
\hline 5 & Aurora & Queer & Public 1 & $\begin{array}{l}\text { Engineering, Manufacturing, and } \\
\text { Construction }\end{array}$ & 5 & QPuIMC05-05 \\
\hline 6 & Orfeo & Gay & Public 1 & Education & 1 & GPuE01-06 \\
\hline 7 & Apolo & Gay & Public 1 & Social sciences and Law & 1 & GPuCSD01-07 \\
\hline 8 & Tristán & Gay & Public 1 & Education & 5 & GPuE05-08 \\
\hline 9 & Hércules & Gay & Public 1 & Social sciences and Law & 5 & GPuCSD05-09 \\
\hline 10 & Hipólito & Gay & Public 1 & Health Sciences & 3 & GPuCS03-10 \\
\hline 11 & Artemisa & Transgender & Public 1 & $\begin{array}{l}\text { Engineering, Manufacturing, and } \\
\text { Construction }\end{array}$ & 5 & TgPuIMC05-11 \\
\hline 12 & Penélope & Lesbian & Private 3 & Social sciences and Law & 9 & LPrCSD09-12 \\
\hline 13 & Theo & Queer & Public 1 & Social sciences and Law & 8 & QPuCSD08-13 \\
\hline 14 & Aria & Bisexual & Public 1 & Social sciences and Law & 1 & BPuCSD01-14 \\
\hline 15 & Bastian & Gay & Public 1 & Arts and Humanities & 5 & GPuAH05-15 \\
\hline 16 & Dante & Gay & Public 1 & Social sciences and Law & 4 & GPuCSD04-16 \\
\hline 17 & Eliú & Gay & Private 4 & Social sciences and Law & 8 & GPrCSD08-17 \\
\hline 18 & Serena & Bisexual & Public 1 & Social sciences and Law & 6 & BPuCSD06-18 \\
\hline 19 & Calixto & Bisexual & Public 1 & $\begin{array}{c}\text { Engineering, Manufacturing, and } \\
\text { Construction }\end{array}$ & 2 & BPuIMC02-19 \\
\hline 20 & Diana & Bisexual & Public 1 & Social sciences and Law & 8 & BPuCSD08-20 \\
\hline 21 & Minerva & Bisexual & Public 1 & Administration and Business & 2 & BPuAN02-21 \\
\hline 22 & Desiré & Lesbian & Private 5 & $\begin{array}{l}\text { Engineering, Manufacturing, and } \\
\text { Construction }\end{array}$ & 4 & LPrIMC04-22 \\
\hline 23 & Tabata & Lesbian & Public 2 & Education & 5 & LPuE05-23 \\
\hline 24 & Silka & Lesbian & Public 1 & Social sciences and Law & 8 & LPuCSD08-24 \\
\hline 25 & Aban & Bisexual & Private 6 & Administration and Business & 2 & BPrAN02-25 \\
\hline 26 & Ezra & Bisexual & Private 7 & $\begin{array}{l}\text { Engineering, Manufacturing, and } \\
\text { Construction }\end{array}$ & 6 & BPrIMC06-26 \\
\hline 27 & Gastón & Gay & Public 3 & Education & 6 & GPuE06-27 \\
\hline 28 & Gaspar & Gay & Private 2 & Health Sciences & 4 & GPrCS04-28 \\
\hline 29 & Hada & Bisexual & Public 1 & $\begin{array}{l}\text { Engineering, Manufacturing, and } \\
\text { Construction }\end{array}$ & 8 & BPuIMC08-29 \\
\hline 30 & Dina & Lesbian & Public 1 & Administration and Business & 2 & LPuAN02-30 \\
\hline 31 & Simón & Gay & Private 8 & Administration and Business & 6 & GPrAN06-31 \\
\hline
\end{tabular}

Note: *The name assigned to the participants of this research is fictitious. ** The ID tag of each participant was made up of the initials of their sexual orientation; the first two letters of the type of financing of their university; the initials of your field of study; semester and, finally, after a dash, the number corresponding to your interview.

Source: own elaboration with the information provided by the research participants. 